\title{
Nilai Tambah Pengembangan Kawasan Wisata Curug Goong Terhadap Kegiatan Ekonomi Masyarakat Secara Berkelanjutan
}

\author{
${ }^{1}$ Yulia Asyiawati, ${ }^{2}$ Saraswati, ${ }^{3}$ Tarlani, ${ }^{4}$ Djamaludin
}

\author{
1,2,3 Program Studi Perencanaan Wilayah dan Kota \\ ${ }^{4}$ Program Studi Teknik Industri, Universitas Islam Bandung, Jalan Tamansari No. 1 Bandung \\ email:1'jully.asyiawati89@gmail.com; ${ }^{2}$ saraswati@unisba.ac.id; ${ }^{3}$ tarlani@unisba.ac.id; \\ 4djamaludin@unisba.ac.id
}

\begin{abstract}
Curug Goong is located in Subang Regency. Located in a strategic location, has natural resources, attractive scenery, and the availability of infrastructure, so that many tourist attractions can be developed. Although this area has not been visited by many tourists, it has potential added value in increasing community economic activities. The purpose of this study is to identify the added value of the Curug Goong tourist area to people's income. The approach method used in this study is a qualitative approach based on phenomena, dynamics, and community perceptions of the area. Using a qualitative approach, data were collected through interviews with the community, observations of the physical and environmental conditions of the area. The findings obtained from this area are natural resources in the form of waterfalls, rivers, agricultural land, gazebos, irrigation networks, open land, and road networks and home industry areas. By using a descriptive analysis, this tourist area can provide added value to people's income in a sustainable manner through the development of natural attractions, cultural tourism, culinary tourism, community creative industry development services, the level of welfare and prosperity of the community increases and environmental conditions remain sustainable, one of the embodiments of the concept. sustainable tourism development.
\end{abstract}

Keywords: tourist area, value added, community, sustainable tourism development.

Abstrak. CCurug Goong terletak di Kabupaten Subang. Berada di lokasi yang strategis, memiliki sumber daya alam, pemandangan yang menarik, dan ketersediaan infrastruktur, sehingga banyak tempat wisata yang dapat dikembangkan. Meskipun kawasan ini belum banyak dikunjungi wisatawan, namun memiliki potensi nilai tambah dalam meningkatkan kegiatan ekonomi masyarakat. Tujuan dari penelitian ini adalah untuk mengidentifikasi nilai tambah kawasan wisata Curug Goong terhadap pendapatan masyarakat. Metode pendekatan yang digunakan dalam penelitian ini adalah pendekatan kualitatif berdasarkan fenomena, dinamika, dan persepsi masyarakat terhadap kawasan tersebut. Dengan menggunakan pendekatan kualitatif, data dikumpulkan melalui wawancara dengan masyarakat, observasi kondisi fisik dan lingkungan kawasan. Temuan yang diperoleh dari kawasan ini adalah sumber daya alam berupa air terjun, sungai, lahan pertanian, gazebo, jaringan irigasi, lahan terbuka, dan jaringan jalan serta kawasan industri rumah tangga. Dengan menggunakan analisis deskriptif, kawasan wisata ini dapat memberikan nilai tambah bagi pendapatan masyarakat secara berkelanjutan melalui pengembangan daya tarik alam, wisata budaya, wisata kuliner, jasa pengembangan industri kreatif masyarakat, tingkat kesejahteraan dan kemakmuran masyarakat meningkat dan kondisi lingkungan tetap lestari, salah satu perwujudan dari konsep tersebut. pengembangan pariwisata berkelanjutan.

Kata Kunci: kawasan wisata, nilai tambah, masyarakat, pembangunan pariwisata berkelanjutan

\section{Pendahuluan}

Sektor pariwisata merupakan salah satu sektor yang memberikan kontribusi terhadap pendapatan wilayah di Kabupaten Subang. Hal ini disebabkan dukungan kekayaan sumberdaya alam yang dimiliki. Salah satu yang dapat dikembangkan adalah objek wisata yang berbasis pada sumberdaya alam, yaitu objek wisata curug yang merupakan pengembangan ekowisata.

Salah satu objek wisata curug yang potensial memberikan kontribusi 
terhadap pendapatan wilayah di Kabupaten Subang adalah objek Wisata Curug Goong di Desa Dayeuhkolot, Kecamatan Sagalaherang (lihat Gambar $1)$.

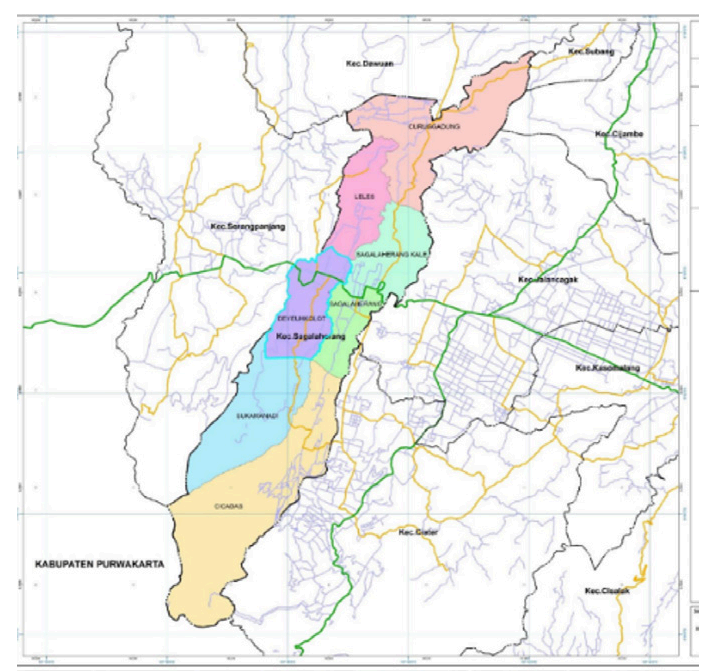

Gambar 1 Peta Orientasi Desa

Curug Goong mempunyai pesona alam luar biasa menarik yang didukung oleh ketersediaan sumberdaya alam, diantaranya kondisi sumberdaya berupa air permukaan (dilintasi oleh Sungai Ciasem) dan sumber mata air di curug baik dari kualitas maupun kuantitasnya, keindahan panorama alamnya, ketersediaan lahan untuk bersantai dan menikmati alam curug dan sekitarnya, kawasan sekitar curug dikeliling oleh hamparan sawah yang indah, dukungan budaya lokal, religi dan edukasi. Komponen atraksi wisata yang sudah mulai dikembangkan pada kawasan wisata Curug Goong ini adalah memancing, body rafting, arung jeram, wisata religi yang terdapat di sekitar kawasan curug dan wisata sejarah. Komponen aksesibilitas yang mendukung dari pengembangan kawasan wisata ini adalah ketersediaan jaringan jalan menuju kawasan wisata, meskipun belum media akses menuju kawasan curug dari jalan raya.

Potensi kawasan wisata Curug Goong ini memberikan eksternalitas terhadap kegiatan ekonomi masyarakat, khususnya masyarakat Desa Dayeuhkolot. Eksternalitas positif dari pengembangan kawasan wisata Curug Goong ini adalah tumbuhnya kegiatan ekonomi baru bagi masyarakat yang memberikan nilai tambah terhadap pendapatan masyarakat khususnya dan pendapatan wilayah desa umumnya, diantaranya kegiatan ekonomi perikanan, kuliner, pengembangan ekonomi kreatif untuk penyediaan cinderamata, penyedia guide wisata, penyedia jasa transportasi

Pada saat ini, kegiatan wisata Curug Goong belum memberikan nilai tambah yang significant bagi masyarakat desa. Hal ini dikarenakan masyarakat belum memahami akan nilai tambah yang akan diperoleh dari kawasan Curug Goong, sehingga kawasan ini tidak dikembangkan sebagaimana potensi yang dimiliki kawasan curug.

Berdasarkan kajian yang sudah dilakukan sebelumnya oleh (Fennell A, 2004) menjelaskan bahwa pengelolaan kawasan ekowisata harus memberikan nilai tambah terhadap lingkungan dan masyarakat lokal dengan konsep meminimalisir dari dampak yang ditimbulkan dari kegiatan pengembangan wisata. Bentuk kegiatan wisata dapat dilakukan pada kawasan yang masih murni dan alami yang bertujuan untuk menikmati kondisi alam, mengetahui, dan memahami budaya dan sejarah kawasan yang dapat memberikan nilai tambah ekonomi yang menguntungkan kepada masyarakat lokal (Butcher, 2007) menjelaskan bahwa pengembangan kegiatan ekowisata, yaitu kegiatan wisata pada kawasan yang masih alami, memperbaiki dan meningkatkan kelestarian lingkungan, dan sumberdaya alam melalui peningkatan kondisi sosial dan ekonomi masyarakat. Kegiatan pengembangan kegiatan ekowisata merupakan salah satu atraksi wisata yang bertujuan untuk meningkatkan pemahaman wisatawan terhadap nilainilai sumberdaya alam dan lingkungan yang secara langsung maupun tidak 
langsung dapat memberikan peningkatan terhadap pendapatan masyarakat lokal (Dokulil, 2014 dalam (Ekasari M, 2019) Di sisi lain Dowling, 1996 dalam Hill \& Gale, 2009 dalam (Tanaya, D. R., \& Rudiarto, 2014) menjelaskan bahwa dalam pengembangan kegiatan ekowisata yang mempunyai 5 (lima) komponen utama yang menjadi karakteristik kegiatan, yaitu mempunyai sifat alamiah, berkelanjutan, edukatif, serta dapat memberikan keuntungan kepada masyarakat lokal sehingga dapat memberikan kepuasan kepada para wisatawan terhadap atraksi yang terdapat di kawasan.

Berdasarkan pada fenomena yang dihadapi Kawasan Wisata Curug Goong, saat ini kawasan belum memberikan nilai tambah terhadap pendapatan masyarakat. Oleh karena itu, kajian yang dilakukan ini bertujuan untuk mengidentifikasi nilai tambah yang dapat diperoleh dari potensi sumberdaya alam di kawasan, sehingga dapat memberikan tambahan terhadap pendapatan masyarakat lokal, khususnya pendapatan masyarakat Desa Dayeuhkolot.

Kajian yang dilakukan di Curug Goong Desa Dayeuhkolot merupakan kajian berdasarkan dari kajian yang telah dilakukan oleh kelima peneliti sebelumnya. Dalam kajian ini, diidentifikasi dari potensi dan masalah pengembangan kawasan wisata berdasarkan potensi dan masalah pengembangan dengan memanfaatkan sumberdaya alam yang ada untuk mendukung pengembangan kawasan dengan atraksi wisata sesuai dengan kondisi wilayah. Nilai tambah dalam kajian ini adalah dampak multiplier effect yang akan diperoleh oleh masyarakat sejalan dengan pengembangan kawasan wisata curug. Kawasan ini dapat dikembangkan untuk kegiatan wisata dan pengembangan kegiatan home industry penyediaan cinderamata untuk wisatawan. Bahan baku yang digunakan untuk pengembangan home industry berasal dari sumberdaya yang terdapat di kawasan dan Desa Dayeuhkolot. Dengan dikembangkannya kawasan wisata Curug Goong dapat memberikan salah satu upaya untuk meningkatkan pendapatan masyarakat di kawasan, sehingga dalam pengembangannya mempertimbangkan kearifan budaya lokal dan dilakukan secara partisipatif.

Hal ini sejalan dengan sasaran strategis dari Kementerian Pariwisata dan Ekonomi Kreatif Republik Indonesia, yaitu meningkatkan kontribusi pariwisata dan ekonomi kreatif dalam mewujudkan ketahanan ekonomi (Peraturan Menteri Pariwisata Dan Ekonomi Kreatif/ Kepala Badan Pariwisata Dan Ekonomi Kreatif Republik Indonesia Nomor 12 Tahun 2020 Tentang Rencana Strategis Kementerian Pariwisata Dan Ekonomi Kreatif/ Badan Pariwisata Dan Ekonomi Kreatif Tahun 2020-2024, 2020).

Dari hasil kajian ini diharapkan dapat memberikan manfaat kepada Pemerintah Desa dalam memberikan masukan arahan kebijakan pengembangan kawasan wisata, sedangkan untuk masyarakat desa dapat memberikan masukan peran kawasan wisata peningkatan kesejahteraan dan pendapatan. Hal ini merupakan suatu upaya yang dilakukan untuk dapat mewujudkan kawasan wisata secara berkelanjutan, dimana secara ekonomi kawasan ini memberikan nilai tambah terhadap peningkatan pendapatan, secara sosial dapat meningkatkan kesejahteraan dan kemakmuran masyarakat desa, sedangkan secara lingkungan, kawasan ini tetap terjaga kelestarian dan keasrian sumberdaya alam untuk menjaga keseimbangan lingkungan.

\section{Metode Ilmiah}

\section{Lokasi Kajian}

Objek kajian ini dilakukan di Desa Dayeuhkolot, Kecamatan Sagalaherang, Kabupaten Subang merupakan objek dari kegiatan Pengabdian kepada Masyarakat 
(PkM). Desa Dayeuhkolot mempunyai luas 430 ha, terdiri dari 4 (empat) dusun, 5 (lima) Rukun Warga dan 21 (dua puluh satu) Rukun Tetangga (RT). Secara administratif, Desa Dayeuhkolot mempunyai batas administrasi di sebelah utara dengan Desa Leles dan Desa Cintamekar (Kecamatan Serangpanjang), sebelah Timur berbatasan dengan Desa Sagalaherang Kidul dan Desa Sagalaherang Kaler, sebelah Barat berbatasan dengan Desa Cijengkol (Kecamatan Serangpanjang), dan sebelah Selatan berbatasan dengan Desa Sukamandi (lihat Gambar 2).

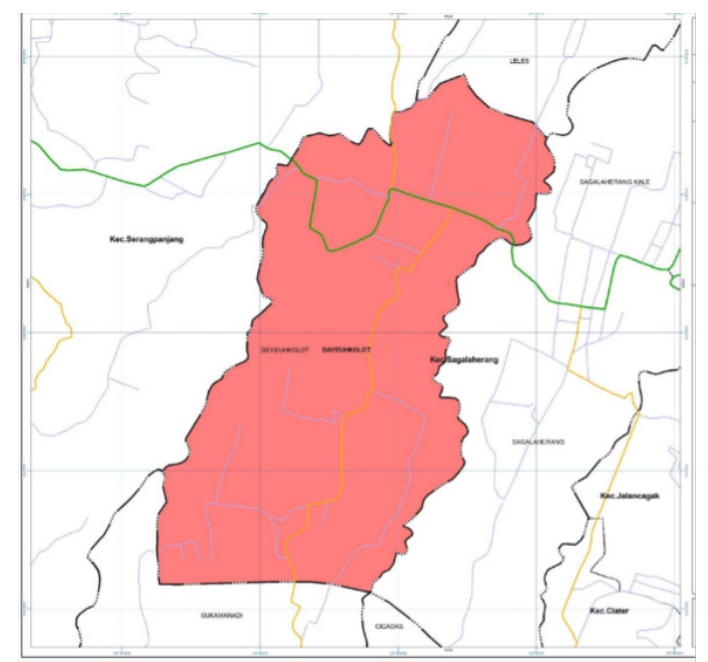

Gambar 2 Peta Desa Dayeuhkolot

\section{Metodologi Kajian}

Tujuan yang diharapkan dari kajian ini, dilakukan dengan menggunakan metode pendekatan secara kuantitatif (Arikunto, 2006). Metode yang digunakan untuk pengumpulan data primer maupun data sekunder adalah metode observasi / groundcheck dan wawancara secara tidak terstruktur. Metode observasi mempunyai tujuan untuk mengidentifikasi penggunaan lahan pada kawasan sekitar Curug Goong. Sementara itu, wawancara tidak terstruktur dilakukan kepada masyarakat sekitar kawasan dengan tujuan untuk mengidentifikasi pemahaman masyarakat terhadap potensi kawasan dan kesiapan masyarakat dalam pengembangan kawasan, sehingga dapat memberikan nilai tambah terhadap pendapatan masyarakat. Hal ini dapat diidentifikasi melalui informasi yang diperoleh dari masayarakat. Respoden diambil secara acak di lokasi studi yang dapat mewakili dari setiap unsur masyarakat desa yang terkait dengan kegiatan wisata dengan metode systematic random sampling, dengan jumlah sampel yang diambil adalah 20 orang. Dari 20 orang responden yang dipilih tersebut merupakan pengurus dari kelompok pecinta pariwisata (KECIWIS) Desa Dayeuhkolot, BUMDes Dayeuhkolot, pelaku industry bamboo, masyarakat yang terdapat di sekitar Curug Goong dan masyarakat yang terdapat di sekitar pelaku industri bambu (home industry). Sedangkan, metode analisis yang digunakan untuk mencapai tujuan dari kajian ini adalah metode analisis deskriptif.

\section{Hasil dan Pembahasan}

\section{Profil Fisik dan Lingkungan}

Desa Dayeuhkolot pada umumnya terletak pada ketinggian $\pm 500 \mathrm{mdpl}$ dengan kemiringan lereng berkisar antara $0-8 \%(79,87 \%$ dari luas desa), sedangkan yang lainnya mempunyai kemiringan lereng $25-40 \%$ (29,62\% dari

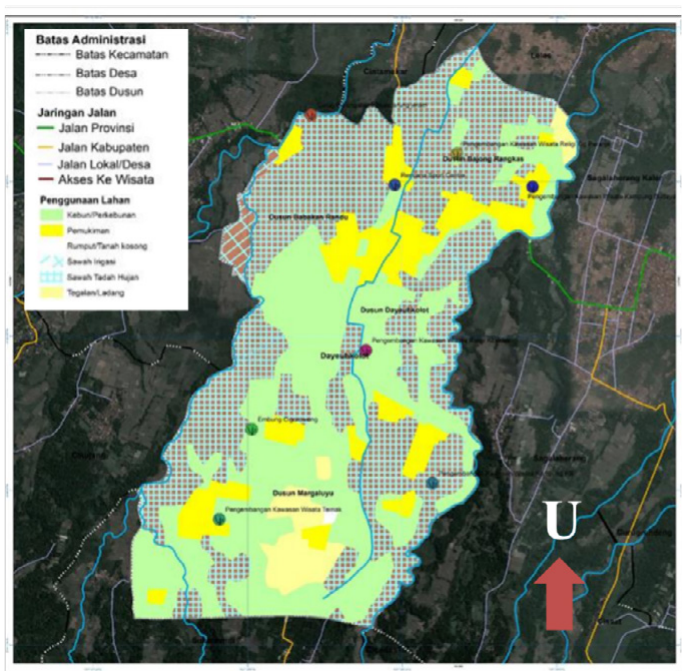

Gambar 3 Peta Penggunaan Lahan 
luas desa) dan yang lainnya mempunyai kemiringan lereng $>40 \%$. Dilihat dari jenis tanah yang membentuk lahan desa, pada umumnya terbentuk dari asosiasi andosol coklat dan regosol coklat. Jenis tanah ini mempunyai tingkat kesuburan dan produktif dibandingkan dengan jenis tanah yang lainnnya. Hal ini dapat dilihat dari jenis penggunaan lahan di Desa Dayeuhkolot didominasi oleh pertanian lahan basah baik sawah beririgasi maupun sawah tadah hujan, yaitu $24,32 \%$ dari luas desa. Sedangkan, penggunaan lahan yang lainnya didominasi oleh penggunaan perkebunan, perumahan dan tegalan (lihat Gambar 3).

Jenis sawah beririgasi mendominasi di Desa Dayeuhkolot $(77,03 \%$ dari luas lahan sawah) karena Desa Dayeuhkolot dilewati oleh Sungai Ciasem, merupakan sungai besar yang terdapat di Kabupaten Subang. Berdasarkan kondisi fisik desa, lahan desa sesuai untuk pengembangan kawasan pertanian, baik pertanian lahan basah, pertanian lahan kering, perkebunan, perikanan, pariwisata, dan permukiman

\section{Profil Sosial Kependudukan}

Desa Dayeuhkolot mempunyai jumlah penduduk pada tahun 2019 adalah 5.389 jiwa dengan rata-rata laju pertumbuhan penduduk 1,89\%/tahun (Badan Pusat Statistik, 2021). Penduduk desa didominasi oleh kelompok umur produktif (umur $20-54$ tahun) yaitu $50,27 \%$ dari jumlah penduduk desa, sedangkan kelompok umur sekolah adalah 23,05\% dari jumlah penduduk desa, sedangkan sisanya adalah kelompok umur $0-4$ tahun $(7,07 \%$ dari jumlah penduduk desa) dan kelompok umur $>$ 55 tahun $(19,61 \%$ dari jumlah penduduk desa) Untuk lebih jelasnya dapat dilihat pada Tabel 1.

Dilihat dari kelompok mata pencaharian, penduduk desa didominasi oleh penduduk yang bermata pencarian sebagai petani $(37,84 \%$ dari jumlah penduduk desa), sedangkan yang lainnya adalah bermata pencarian pada sektor pertambangan dan penggalian, industri, konstruksi, perdagangan hotel dan restoran, sektor angkutan, sektor jasa dan sektor lainnya. Dilihat dari kelompok mata pencarian yang diusahakan oleh masyarakat desa Dayeuhkolot dapat diidentifikasi bahwa masyarakat desa sudah ada yang bekerja mendukung pada sektor pariwisata, diantaranya adalah sektor perdagangan, hotel dan restoran, sektor jasa, sektor angkutan, dan sektor industri.

Tabel 1. Jumlah Penduduk Menurut Kelompok Umur Desa Dayeuhkolot, Tahun 2019

\begin{tabular}{ccc}
\hline No & $\begin{array}{c}\text { Kelompok Umur } \\
\text { (tahun) }\end{array}$ & Jumlah (jiwa) \\
\hline 1 & $0-4$ & 381 \\
\hline 2 & $5-9$ & 431 \\
\hline 3 & $10-14$ & 403 \\
\hline 4 & $15-19$ & 408 \\
\hline 5 & $20-24$ & 418 \\
\hline 6 & $25-29$ & 368 \\
\hline 7 & $30-34$ & 314 \\
\hline 8 & $35-39$ & 418 \\
\hline 9 & $40-44$ & 378 \\
\hline 10 & $45-49$ & 442 \\
\hline 11 & $50-54$ & 371 \\
\hline 12 & $>55$ & 1057 \\
\hline & Jumlah & 5389 \\
\hline
\end{tabular}

Kondisi budaya masyarakat Desa Dayeuhkolot yang menjadi penciri desa adalah "ruwatan bumi", merupakan acara syukuran atas nikmat yang sudah diberikan oleh Allah. Dari hasil wawancara yang dilakukan kepada tokoh masyarakat desa, ruwatan bumi dilaksanakan sekali dalam 1 (satu) tahun, yaitu pada bulan Safar. Atraksi yang dilakukan pada acara ruwatan bumi adalah dengan cara mengumpulkan sebagain hasil tani masyarakat, kemudian memanjatkan doa kepada Allah. Acara ini ada yang diselingi dengan tayangan wayang golek sebagai hiburan, ada juga yang tidak. Acara ini dilakukan di 
Balai Pertemuan Desa atau dapat juga dilakukan ditempat lain sesuai dengan hasil kesepakatan warga desa.

\section{Profil Ekonomi Masyarakat}

Kegiatan perekonomian masyarakat Desa Dayeuhkolot meliputi kegiatan pertanian padi, pertanian holtikultura, perkebunan, perindustrian, dan kegiatan pariwisata. Kegiatan yang mendominasi saat ini di Desa Dayeuhkolot adalah kegiatan ekonomi pertanian dan industri yang mendukung pertanian. Hal ini didukung dengan ketersediaan sarana dan prasarana yang mendukung pada kegiatan ekonomi tersebut, seperti penggilingan padi, industri kerajinan rumah tangga berbahan baku bambu. Dari semua kegiatan perekonomian yang terdapat di Desa Dayeuhkolot, dapat dijadikan pendukung pengembangan industri pariwisata yang akan dikembangkan di Desa Dayeuhkolot.

\section{Profil Sarana dan Prasarana}

Kondisi sarana yang terdapat di Desa Dayeuhkolot adalah sarana perdagangan, pendidikan, peribadatan, kesehatan, sarana dan sarana sosial berupa balai pertemuan. Sarana yang khusus mendukung untuk pengembangan kawasan wisata di desa ini belum tersedia secara khusus di kawasan wisata.

\section{Profil Kawasan Wisata Curug Goong}

Desa Dayeuhkolot mempunyai beberapa kawasan yang memiliki potensi sumber daya alam untuk dikembangkan sebagai kawasan wisata. Sumber daya alam yang terdapat pada kawasan Wisata Curug Goong adalah sumber daya curug dengan ketinggian \pm 8 meter, hamparan kolam dengan kedalaman $\pm 2,5$ meter, aliran air sungai dengan lebar badan sungai \pm 300 meter, batuan kali yang terdistribusi pada bentangan sungai, hamparan sawah, lahan terbuka, jaringan irigasi dengan sumber air yang jernih, gazebo, jaringan jalan menuju kawasan curug, jaringan jalan menuju kawasan industri cinderamata, embung Cigorowong, kuburan sesepuh kawasan, budaya lokal, dan ketersediaan sarana ibadah dan warung makan/makanan.

Berdasarkan potensi sumber daya alam yang tersedia, Kawasan Curug Goong memiliki potensi untuk dikembangkan sebagai kawasan wisata dengan penawaran atraksi yang dibagi menjadi beberapa klasifikasi, yaitu: (1) wisata alam, terdiri dari kawasan wisata curug Goong, Embung Cigorowong; (2) wisata religi, terdiri dari wisata religi kibodas, wisata religi Gunung Paranje; (3) wisata budaya terdiri dari wisata kampung budaya, wisata kampung KB; (4) wisata pertanian meliputi wisata ternak dan (5) wisata olahraga (lihat Gambar 4).

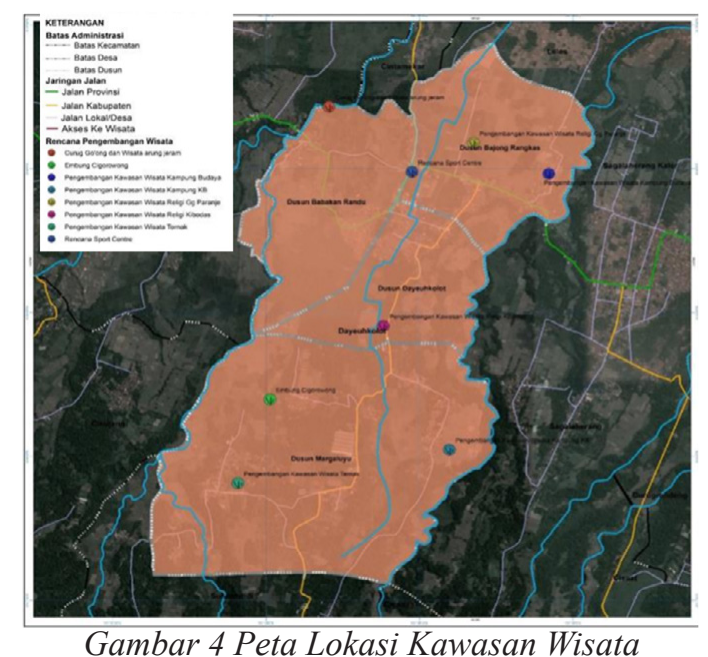

Berdasarkan hasil wawancara yang dilakukan dengan tokoh masyarakat di Desa Dayeuhkolot, nama Curug Goong berasal dari cerita masyarakat yang membawa rombongan seni melintasi curug dimana alat musik goongnya jatuh ke dalam lubang yang terdapat dalam air curug. Hal ini dapat dijadikan sebagai penciri dari kawasan ini. Sumber air dari Curug Goong adalah Sungai Ciasem dengan debit air sangat besar, dengan kualitas air yang baik, dan jernih.

Atraksi wisata yang sudah dikembangkan pada kawasan wisata Curug Goong ini adalah wisata memancing, wisata arung jeram (masih 
terbatas), body rafting (masih terbatas), berendam, berjemur sambil menikmati pemandangan alam dikelilingi oleh sawah dengan pola terasering yang masih asri dan alami.

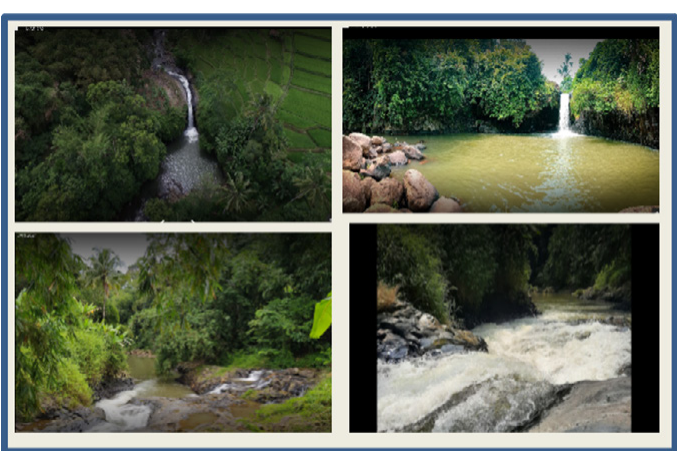

Gambar 5 Kondisi Curug Goong

Pada Saat ini wisatawan yang berkunjung ke kawasan wisata ini masih terbatas dan belum ada retribusi yang dibebankan kepada wisatawan. Hal ini dikarenakan kawasan ini belum memadai untuk melakukan semua atraksi wisata yang potensial tersebut. Masih diperlukan penataan lebih baik agar atraksi wisata yang dilakukan di kawasan ini terasa aman dan nyaman. Di samping itu, kawasan ini belum dilengkapi komponen amenitas dan komponen aksesibilitas menuju curug yang memadai. Akses menuju curug dari ruas jalan Subang-Purwakarta dapat dilalui dengan menyusuri pematang sawah yang ada, sehingga menjadi kendala untuk mencapai curug. Sementara itu, hamparan lahan untuk melakukan kegiatan berjemur atau bersantai masih berupa hamparan bergelombang, sehingga memberikan kondisi yang kurang nyaman dan kurang aman untuk melakukan atraksi.

Oleh karena itu, kawasan wisata Curug Goong ini perlu dilakukan

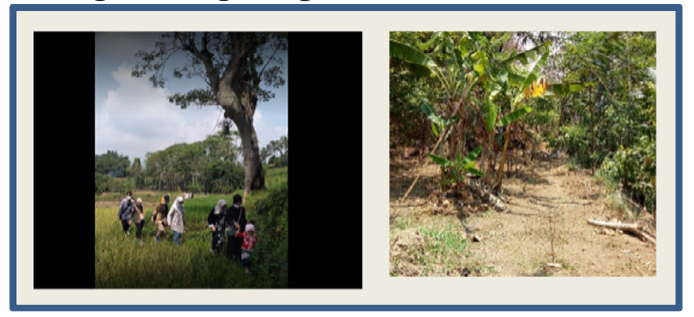

Gambar 6 Kondisi Aksesibilitas Menuju Curug penataan agar memberikan kenyamanan dan keamanan dalam melakukan atraksi wisata. Berdasarkan data yang diperoleh dari kelompok pecinta pariwisata (KECIWIS) Desa Dayeuhkolot, bahwa kawasan wisata Curug Goong sudah mulai dikenal dan diminati oleh wisatawan karena atraksi wisata yang ditawarkan menarik dan memiliki pesona alam yang indah.

Kawasan wisata Curug Goong dapat melakukan link wisata dengan kawasan wisata lainnya di Desa Dayeuhkolot, maupun dengan kawasan wisata yang berada di sekitar desa Dayeuhkolot. Karena masing-masing kawasan wisata tersebut menawarkan atraksi wisata yang berbeda-beda, sehingga akan memberikan potensi tarikan untuk pengembangan kawasan dan memberikan nilai tambah untuk pengembangan kawasan (lihat Gambar 7).

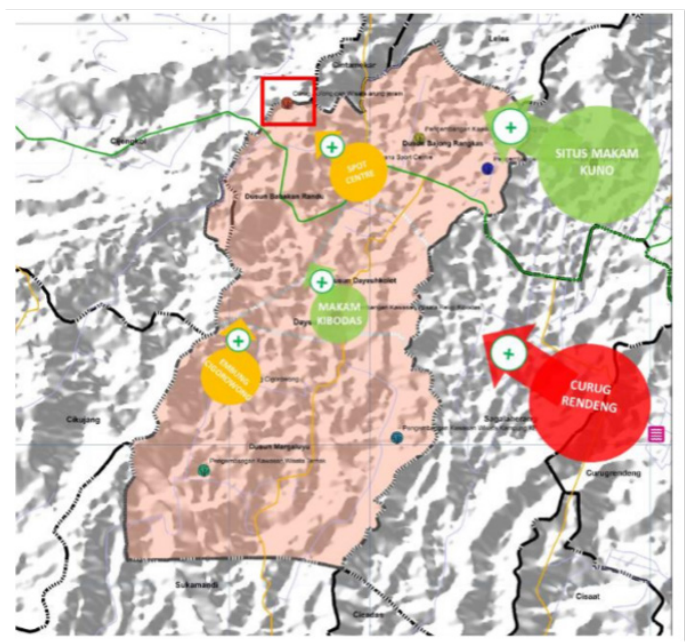

Gambar 7 Potensi Link Kawasan Wisata

\section{Profil Sistem Kelembagaan}

Robustin, Sularso, \& Suroso, 2018 dalam Linda et. al, 2018 menjelaskan bahwa dalam pengelolaan kawasan wisata diperlukan sistem pengelolaan yang bersinergi antara pemerintah, masyarakat, dan potensi kawasan serta wisatawan/pengunjung. Faktor utama yang memengaruhi pengembangan suatu kawasan wisata adalah atraksi yang ditawarkan, aksesibilitas dari dan 
menuju kawasan wisata, ketersediaan fasilitas, dan kenyamanan dari kawasan wisata (Robustin et al., 2018 dalam Linda et. al, 2018). Disamping itu, untuk dapat berkembangnya kawasan wisata dengan baik adalah dengan melibatkan partisipasi aktif masyarakat melalui kelompok wisata (Prihantini I et al., 2019).

Pada saat ini Desa Dayeuhkolot sudah mempunyai kelompok Pencinta Pariwisata (KECIWIS) yang dibentuk oleh masyarakat pencinta wisata dan sumber daya alam yang diakui oleh Pemerintah Desa. KECIWIS melakukan kerjasasama dengan Badan Usaha Milik Desa (BUMDesa) dalam mengelola kawasan wisata yang terdapat di desa, sehingga dapat memberikan informasi timbal balik untuk pengembangan kawasan wisata di desa. Dengan adanya binaan kerja sama, antara KECIWIS dengan BUMDes akan memberikan kemudahan dalam melakukan pengelolaan kawasan wisata di Desa Dayeuhkolot di masa yang akan datang.

Dalam pengelolaan kawasan Wisata Curug Goong saat ini, belum berjalan dengan baik karena kegiatan wisata pada kawasan kawasan ini belum berjalan dengan baik. Melalui adanya KECIWIS ini memberikan peluang untuk pengembangan kawasan wisata Curug Goong menjadi lebih baik di masa yang akan datang, sehingga pengembangan dan pengelolaan kawasan wisata dapat menglibatkan partisipasi masyarakat dengan baik.

\section{Identifikasi Pemahaman dan Kesiapan Masyarakat}

Untuk mengetahui tingkat pemahaman dan kesiapan masyarakat terhadap kegiatan dan pengembangannya dari kawasan wisata Curug Goong dilakukan dengan melakukan wawancara yang tidak terstruktur kepada masyarakat dengan menggunakan metode systematic random sampling. Adapun muatan wawancara yang susun adalah (1) pengetahuan masyarakat terhadap kegiatan wisata pada kawasan curug goong; (2) pengetahuan masyarakat akan rencana pengembangan kawasan wisata Curug Goong; (3) pengetahuan masyarakat tentang pengembangan industri rumahan (home industry) untuk mendukung dari kawasan wisata sebagai penyedia cinderamata; (4) kesiapan masyarakat dalam pengembangan kawasan wisata dan pengembangan indutri rumahan untuk penyedia cinderamata.

Dari 20 responden yang ditanya, teridentifikasi bahwa pada umumnya masyarakat belum mengetahui atraksi yang sudah ada dan yang akan dikembangkan di kawasan wisata Curug Goong (68\%), sedangkan 32\% dari responden sudah mengetahuinya. Adapun responden yang sudah mengetahui keberadaan kegiatan atraksi wisata dan rencana pengembangannya adalah masyarakat aktif dan termasuk ke dalam sistem kelembagaan desa, sedangkan masyarakat pada umumnya belum mengetahui tentang hal tersebut. Terkait dengan kegiatan home industry yang dapat dikembangkan oleh masyarakat untuk mendukung dari pengembangan kawasan wisata ini belum diketahui oleh masyarakat, termasuk pengrajin atau pengusaha. Karena usaha yang dilakukan oleh masyarakat saat ini, membuat kerajinan yang dapat dijadikan cenderamata itu adalah dibuat sesuai dengan permintaan dari konsumen saja, tidak dilakukan produksi setiap hari, dan hal itu demand-nya berasal dari luar kawasan. Sedangkan, sewaktu ditanya tentang kesiapan masyarakat untuk pengembangan kawasan ini menjadi kawasan wisata dengan atraksi yang dapat dikembangkan sesuai dengan potensi dan kesiapan dari pengrajin bingkisan cinderamata. Masyarakat sangat mendukung arah kebijakan pengembangan kawasan dan kegiatan yang akan dikembangkan. Dengan harapan, pengembangan kegiatan pada 
kawasan Curug Goong sebagai kawasan wisata dapat memberikan peluang bagi masyarakat dalam mengembangkan usaha mereka, baik dalam pengembangan usaha perdagangan, kuliner, kerajinan dari bambu (merupakan produk di Desa Dayeuhkolot), jasa pelayanan wisata, jasa transportasi dan lain-lain, sehingga kawasan wisata ini dapat dikembangkan secara berkelanjutan untuk kesejahteraan dan kemakmuran masyarakat.

\section{Konsep Pengembangan Kawasan Wisata Curug Goong Berkelanjutan}

Curug merupakan salah satu potensi sumber daya alam untuk mengembangkan kegiatan pariwisata secara berkelanjutan. Dilihat dari fungsinya, curug mempunyai fungsi ekologis sebagai reservoir air atau menampung air dari sumber mata air dan air permukaan, sehingga dapat menjaga kondisi hidrologi. Curug merupakan formasi geologi berasal dari arus air yang mengalir melewati suatu formasi bebatuan yang mengalami erosi dan jatuh ke bawah berasal dari ketinggian. Oleh karena itu, pengembangan curug sebagai kawasan wisata dapat memberikan nilai tambah terhadap atraksi wisata air dari keberadaan curug. Sementara itu, fungsi lainnya dari air yang berasal dari curug dapat dimanfaatkan sebagai pengairan lahan sawah, perikanan, dan untuk memenuhi kebutuhan air bersih dari masyarakat, begitu juga halnya dengan keberadaan dari Curug Goong.

Tentu saja dengan mempertimbangkan kondisi fisik, lingkungan, sosial kependudukan, ekonomi, sarana dan prasarana serta ketersediaan sumber daya alam yang mendukung pengembangan kawasan wisata di Desa Dayeuhkolot, konsep pengembangan kawasan wisata yang diterapkan adalah pengembangan kawasan wisata secara berkelanjutan dan terpadu. Hal ini dapat dilakukan dengan mengembangkan kawasan wisata terpadu dengan mengintegrasikan beberapa potensi kelompok wisata yang ada di desa menjadi link wisata antar kawasan dengan beberapa atraksi wisata yang ditawarkan berbeda-beda, yaitu wisata alam curug goong, wisata religi, dan wisata budaya, dengan icon dari kawasan wisata di Desa Dayeuhkolot adalah Kawasan Wisata Curug Goong. Untuk dapat memberikan kenyaman kepada para wisatawan, dilengkapi dengan penyediaan sarana dan prasarana untuk mengembangkan dan menjangkau masing-masing atraksi yang ditawarkan pada setiap kawasan wisata yang terdapat di desa Dayeuh Kolot. Mewujudkan kawasan ini untuk dapat dikembangkan secara baik didukung dalam pelaksanaannya oleh KECIWIS dengan melibatkan partisipasi aktif dari setiap kelompok masyarakat di kawasan, sehingga kawasan wisata dapat berkembang dengan baik (Tanaya, D. R., \& Rudiarto, 2014).

Oleh karena itu, untuk mendukung pengembangan kawasan wisata yang terpadu, dikembangkan atrakasi wisata berbeda-beda untuk setiap kawasan. Untuk Kawasan Wisata Curug Goong, perlu dilengkapi komponen/atribut wisata kawasan agar memberikan daya tarik yang kuat. Adapun komponen wisata yang perlu dikembangkan dan ditata adalah :

a. Atraksi wisata. Untuk mendukung pengembangan atraksi wisata berupa arung jeram, body rafting adalah menata kawasan sekitar curug agar tidak membahayakan bagi wisatawan. Sedangkan untuk atraksi wisata memancing, berendam harus menyiapkan zona tersendiri agar tidak mengganggu antara satu atraksi dengan atraksi yang lainnya. Sedangkan atraksi berjemur atau beristirahat menikmati pesona alam kawasan yang indah, dapat dilakukan dengan menata dan membuat tapak kawasan yang rata, sehingga memberikan kenyamanan untuk wisatawan dalam beristirahat. Untuk penataan kawasan ini 
dapat dilakukan oleh pemerintah daerah, swadaya masyarakat atau swasta. Atraksi wisata yang lain yang dapat dikembangkan adalah wisata edukasi pertanian karena lahan kawasan mempunyai jenis tanah asosiasi andosol coklat dan regosol coklat yang sesuai dikembangkan untuk kawasan pertanian (Balai Besar Penelitian dan Pengembangan Sumberdaya Lahan Pertanian Badan Penelitian dan Pengembangan, 2014). Hal ini juga, didukung oleh ketersediaan jaringan irigasi yang terdapat pada kawasan.

b. Amenitas. Hal ini dapat dilakukan dengan menyiapkan saran dan prasarana pendukung kenyamanan dan kebutuhan wisatawan, diantaranya adalah sarana kuliner, sarana penjualan cinderamata. Untuk sarana kuliner diarahkan untuk masing-masing kawsaan wisata desa, sedangkan untuk sarana cinderamata terpusat pada 1 (satu) kawasan di Kampung Cigorowong, dimana sumber bahan baku yang digunakan untuk cinderamata berasal dari sumberdaya alam yang terdapat pada desa.Pengembangan amenitas wisata dapat dilakukan oleh masyarakat desa.

c. Aksesibilitas. Untuk mendukung aksesibilitas, harus dibangun jalan yang memberikan kenyaman dan kemudahan bagi wisatawan untuk mencapai kawasan curug. Sedangkan untuk konektivitas antar kawasan wisata yang terdapat di desa, dikembangkan angkutan khusus wisata yang melayani perjalanan wisatawan ke kawasan wisata yang ada. Hal ini dapat dilakukan oleh masyarakat desa.

\section{Nilai Tambah Kawasan Wisata}

Indikator yang digunakan dalam mengukur nilai tambah pengembangan Kawasan Wisata Curug Goong melalui pendekatan peningkatan kegiatan sosial-ekonomi masyarakat secara berkelanjutan. Berdasarkan konsep rencana pengembangan kawasan wisata Curug Goong yang dibuat, diharapkan rencana pengembangan Kawasan Wisata Curug Goong dapat menjadi prime mover bagi pengembangan kawasan wisata di Desa Dayeuhkolot. Hal ini dapat membuka peluang untuk pengembangan kegiatan sosial-ekonomi di kawasan wisata, sehingga memberikan nilai tambah terhadap kondisi sosial-ekonomi masyarakat desa.

Nilai tambah yang dapat diidentifikasi dari rencana penataan dan pengembangan kawasan wisata Curug Goong adalah:

a. Pengembangan usaha kegiatan perdagangan di kawasan wisata. Perdagangan yang dapat dikembangkan adalah jenis makanan dan minuman.

b. Membuka usaha jasa penyewaan alat-alat untuk body rafting atau arung jeram.

c. Membuka usaha untuk pengembangan budaya lokal sebagai salah satu atraksi yang dapat ditawarkan.

d. Meningkatkan kegiatan industri kreatif yang dapat dijadikan cenderamata bagi wisatawan.

e. Membuka jasa usaha transportasi wisata yang melayani wisatawan menuju ke kawasan wisata yang terdapat di desa

f. Menyediakan jasa parkir

g. Menyediakan pengelola kawasan wisata secara profesional dengan memberdayakan masyarakat lokal.

h. Pengembangan kegiatan perikanan disepanjang jaringan irigasi, di sekitar kawasan curug. Ini juga memberikan atraksi menarik untuk kawasan wisata.

Pengembangan kegiatan ekonomi akibat dari pengembangan kawasan wisata terpadu di Desa Dayeuhkolot 
khususnya adalah kawasan wisata Curug Goong, memberikan nilai tambah manfaat yang dirasakan dan dinikmati oleh masyarakat desa. Manfaat utama adalah meningkatnya kegiatan sosial-ekonomi masyarakat secara langsung dan tidak langsung akan memberikan peningkatan terhadap pendapatan masyarakat desa. Di samping itu, dengan adanya rencana untuk mengembangkan kawasan wisata ini membuka peluang kerja kepada masyarakat desa untuk sektor informal, sehingga memberikan manfaat untuk mengurangi angka pengangguran di desa. Kondisi ini akan memberikan pengaruh terhadap peningkatan pendapatan masyarakat, sehingga tingkat kesejahteraan masyarakat akan meningkat. Di samping itu juga, dari rencana pengembangan kawasan wisata ini akan dapat mempublikasikan kepada masyarakat luas dan wisatawan tentang budaya lokal dan indutri kecil yang diproduksi oleh masyarakat berupa hasil kerajinan masyarakat bersumber pada sumber daya alam lokal.

Rencana pengembangan Kawasan Wisata Curug Goong ini, merupakan konsep dari pengembangan kawasan wisata secara berkelanjutan karena pengembangan kegiatan dan kawasan tetap melestarikan kondisi sumber daya alam dan lingkungan, kondisi ekonomi masyarakat meningkat dan tingkat kesejahteraan serta kemakmuran masyarakat akan meningkat. Hal ini merupakan perwujudan tujuan dari pengembangan pariwisata nasional, yaitu meningkatkan pertumbuhan ekonomi; meningkatkan kesejahteraan rakyat; menghapus kemiskinan; mengatasi pengangguran; melestarikan alam, lingkungan, dan sumber daya; memajukan kebudayaan; mengangkat citra bangsa (Undang-Undang Nomor 10 Tahun 2009 Tentang Kepariwisataan, 2009).

\section{Kesimpulan dan Saran}

Dari pembahasan yang sudah dilakukan, dapat disimpulkan bahwa Kawasan Wisata Curug Goong mempunyai potensi yang sangat besar untuk dikembangkan. Nilai tambah yang diperkirakan akan diperoleh dari rencana pengembangan kawasan Curug Goong adalah tumbuhnya kegiatan sosialekonomi masyarakat yang merupakan multiplier effect dari pengembangan kawasan. Nilai tambah yang diperoleh dari pengembangan kawasan wisata ini adalah menciptakan lapangan kerja baru untuk kegiatan sosial-ekonomi yang tumbuh, termasuk kegiatan pelestarian budaya lokal dan pengembangan industri kreatif yang sudah ada dalam masyarakat. Hal tersebut dapat meningkatkan pendapatan, kesejahteraan, dan kemakmuran masyarakat. Di sisi lain kondisi sumber daya alam Curug dapat dijaga kelestarian dan keasriannya, sehingga fungsi hidrologis curug sebagai penyedia air baku untuk kegiatan pertanian, perikanan, dan memenuhi kebutuhan hidup masyarakat akan air bersih tetap terjaga. Hal ini merupakan perwujudan dari pembangunan kawasan wisata berkelanjutan di Desa Dayeuhkolot.

Dari hasil kajian yang dilakukan, rekomendasi yang dapat diberikan dalam pengembangan kawasan wisata Curug Goong harus dilakukan secara terpadu dan komprehensif dengan kawasan wisata lainnya yang terdapat di Desa Dayeuhkolot, sehingga akan memberikan nilai tambah yang significant terhadap pengembangan wilayah secara berkelanjutan.

\section{DAFTAR PUSTAKA}

Arikunto, S. (2006). Prosedur Penelitian : Suatu Pendekatan Praktis (Cet. 13). Rineka Cipta.

Badan Pusat Statistik. (2021). Kecamatan Sagalaherang Dalam Angka 2020. 
Balai Besar Penelitian dan Pengembangan Sumberdaya Lahan Pertanian Badan Penelitian dan Pengembangan. (2014). Tanah Andosol di Indonesia.

Butcher, J. (2007). Ecotourism, NGOS and Development. https://doi.org/https://doi. org/10.1080/09669580802159743

Ekasari M, A. (2019). Menilai Kelayakan Pengembangan Situ-Situ Di Kabupaten Bekasi Sebagai Obyek Destinasi Wisata. Ethos: Jurnal Penelitian Dan Pengabdian Kepada Masyarakat, Vol 7, No., 244-254. https://ejournal.unisba.ac.id/index. php/ethos/article/view/4572

Fennell A, D. (2004). Ecotourism An Introduction (2nd Editio). Routledge.

Peraturan Menteri Pariwisata dan Ekonomi Kreatif/Kepala Badan Pariwisata dan Ekonomi Kreatif Republik Indonesia Nomor 12 Tahun 2020 tentang Rencana Strategis Kementerian Pariwisata Dan Ekonomi Kreatif/ Badan Pariwisata Dan Ekonomi Kreatif Tahun 2020-2024. (2020). https:// peraturan.bpk.go.id/Home/ Details/169207/permenpar-no-12tahun-2020

PkM, L. (2020). Kajian Kelayakan Ekowisata Berbasis Tata Nilai Lingkungan dan Kearifan Budaya Lokal di Desa Dayeuhkolot. LPPM Universitas Islam Bandung. Bandung.

PkM, L. (2021). Pendampingan Strategi Rencana Implementasi (Action Plan) Desa Dayeuhkolot, sebagai Desa Wisata. LPPM Universitas Islam Bandung. Bandung.

Prihantini I, C., Lutfiyanto, Musoffan, \& Darwis. (2019). Pemberdayaan Kelompok Sadar Wisata (PokDarwis) Sebagai Penggerak Kemajuan Wisata Edukasi Jumiang. Ethos : Jurnal Penelitian Dan Pengabdian Kepada Masyarakat, 7
No.2. https://ejournal.unisba.ac.id/ index.php/ethos/article/view/4722

Tanaya, D. R., \& Rudiarto, I. (2014). Potensi Pengembangan Ekowisata Berbasis Masyarakat Di Kawasan Rawa Pening, Kabupaten Semarang. Teknik PWK (Perencanaan Wilayah Kota), 3(1), 71-81. https://ejournal3. undip.ac.id/index.php/pwk/article/ view/4389

Undang-undang Nomor 10 tahun 2009 tentang Kepariwisataan. (2009). LN. 2009/No.11, TLN Nomor 4966, LL Set Neg: 40 halaman. https://peraturan.bpk.go.id/ Home/Details/38598/uu-no-10tahun-2009 